\title{
ENDOSCOPIC DIAGNOSTICS OF CHRONIC DISEASES OF THE NASAL CAVITY IN DOGS
}

\author{
Z KNOTEK, T. FICHTEL, R. HUSNÍK, J. BENÁK \\ Small Animal Clinic, Faculty of Veterinary Medicine \\ University of Veterinary and Pharmaceutical Sciences, Brno, Czech Republic
}

Received July 31, 2000

Accepted November 22, 2000

\begin{abstract}
Knotek Z, T. Fichtel, R. Husník, J. Benák: Endoscopic Diagnostics of Chronic Diseases of the Nasal Cavity in Dogs. Acta Vet. Brno 2000, 69:319-326.

Results of a two-year project focused on diagnostic efficacy of various endoscopic techniques and their combination in 52 dogs affected by chronic diseases of the nasal cavity are presented. The rigid endoscope Hopkins (diameter $2.7 \mathrm{~mm}$, length $18 \mathrm{~cm}$, Karl Storz, Tuttlingen) and the flexible endoscope Olympus BF Type PE (Olympus Optical Co., Hamburg) were used for anterior and posterior rhinoscopy, respectively. Bioptic samples of damaged nasal tissues were collected under endoscopic guidance, fixed in $10 \%$ buffered neutral formaldehyde for 12 to $24 \mathrm{~h}$ and processed by the conventional paraffin technique. Deep swabs for bacteriological and mycological examinations were also collected under rhinoscopic guidance. Bacterial and fungal rhinitis and neoplasms were diagnosed in $50 \%, 19.2 \%$, and $23.1 \%$ of the patients, respectively. Foreign bodies were found in four patients $(7.7 \%)$. Three patients affected by mycotic rhinitis developed fungal plaques on the nasal mucosa. The passage of endoscope was completely blocked by tumours in the anterior part of the nasal cavity in two patients. Destructive lesions were found mostly in patients with chronic nasal problems (aspergillosis, foreign body, chronic bacterial infection). Anterior rhinoscopy with a rigid endoscope and posterior rhinoscopy with a flexible endoscope yielded correct diagnoses in $55.8 \%$ and $26.9 \%$ of the patients, respectively. Examination by both the techniques increased this proportion to $82.7 \%$. The reliability of histological examination of tissue samples collected by endoscope-assisted biopsy was $94.4 \%$, while that of the other laboratory test only $41.7 \%$. Rhinoscopy can significantly improve the reliability of diagnosis of canine chronic diseases of the nasal cavity.

Rhinoscopy, rhinitis, nasal tumours in dogs
\end{abstract}

Diseases of the nasal cavity in dogs often develop into a complicated chronic process. Predisposed to such diseases are above all dolichocephalic breeds (Retriever, Collie, German Shepherd Dog). Endonasal neoplasms develop slowly, but involve progressively large areas of the nasal cavity and seriously affect the physiology of breathing. The most conspicuous clinical signs of pathological processes affecting the nasal and paranasal cavities include nasal discharge and sneezing. As the disease acquires chronic character, the frequency and intensity of sneezing decrease and nasal discharge becomes the dominant sign. Inflammation develops as an acute health problem, but often acquires chronic character. Chronic rhinitis with relapsing epistaxis can indicate allergic character of the disease (Forbes Lent and Hawkins 1992). The initially clear and unilateral discharge becomes purulent, haemorrhagic, and bilateral. Inspiration becomes laborious, because obstacles in the nasal airways increase air resistance by 50 to $70 \%$ of the values considered normal in healthy quiescent dogs (Robinson 1992). Erosions, ulcerations and loss of pigment are apparent on the outer surface of nostrils. Advanced stages are characterised by destruction and distorsion of the nasal cavity. Patients affected by diseases of the nasal cavity, nasopharynx, or paranasal cavities develop nasal discharge, epistaxis, stridor, and facial oedema. The process is bilateral in approximately one half of the patients. 
The aetiology of diseases of the nasal cavity in small animals is rather manifold (Forbes Lent and Hawkins 1992; Ogilvie and LaRue 1992; Wolf 1992; Caniatti et al. 1998ab; Knotek et al. in press). Therefore, comprehensive approach to diagnostics is necessary ( $\mathrm{V}$ an Pelt and McKiernan 1994). Endoscopic examination has become an unavoidable part of complete clinical examination of patients suffering from nasal problems (Willard and Radlinsky 1994). Rhinoscopy is a method for visualisation of the nasal cavity. A variety of endoscopic instruments are available for this method which yields information that would be difficult to obtain otherwise (Caniatti et al. 1998ab; Forbes Lent and Hawkins 1992; McCullough et al. 1998; Ogilvie and LaRue 1992; Théon et al. 1995; Willard and Radlinsky 1999). Rhinoscopy is indicated particularly in cases when it is necessary to collect bioptic samples for laboratory examination, or to specify the type and extent of the disease, such as a nasal tumour, before therapy is started (Rebar et al. 1992). Human and veterinary surgeons use rhinoscopy also for the treatment of complications, removal of foreign bodies from the nasal cavity, or special drug administration (Vokurka et al. 1998; Willard and Radlinsky 1999). Some complications can acquire peracute character and rhinoscopy becomes the method of choice for both diagnostics and therapy (Padrid and McKiernan 1999). Suitable anaesthetic method must be chosen to prevent injury to the patient (Robertson 1999). The choice of endoscopic instruments depends on the area of the nasal cavity to be examined (Table 1). Considering the anatomical arrangement of the nasal cavity, anterior and posterior rhinoscopy can be distinguished (Padrid and McKiernan 1999; Willard and Radlinsky 1999).

Table 1

Pros and contras of rigid and flexible endoscopes for rhinoscopy in dogs (ref. Padrid and McKiernan 1999)

\begin{tabular}{|c|c|c|c|c|}
\hline Type & $\begin{array}{c}\text { Anterior } \\
\text { rhinoscopy }\end{array}$ & $\begin{array}{c}\text { Posterior } \\
\text { rhinoscopy }\end{array}$ & Mean price & $\begin{array}{c}\text { Biopsy of nasal } \\
\text { tissues }\end{array}$ \\
\hline Rigid & suitable & unsuitable & high & Yes \\
\hline Flexible & suitable & suitable & very high & Yes \\
\hline
\end{tabular}

Anterior rhinoscopy is characterised by the approach through nostrils. Rigid or flexible endoscope is introduced along the septum into spaces delineated by the dorsal, middle, and ventral turbinates. The ventral turbinate runs in folds and, along with the dorsal turbinate, delimits the passage of the endoscope through the rostral part of the nasal cavity. The middle (ethmoid) turbinate is located aborally. The turbinates divide the nasal cavity in three narrow compartments. The dorsal compartment is demarcated by the nasal bone and the dorsal turbinate, the middle compartment by the dorsal and ventral turbinates, and the ventral compartment by the ventral turbinate and the hard palate. The use of rigid endoscopes is associated with the risk of injury to the nasal mucosa and bleeding (Sullivan 1987). A drawback of anterior rhinoscopy is the rather narrow space of nostrils in brachycephalic dog breeds.

Posterior rhinoscopy allows the assessment of the state of choanae and nasopharynx. Flexible endoscope is introduced through the oral cavity and along the soft palate and its end is directed rostrally towards choanae (Padrid and McKiernan 1999; Willard and Radlinsky 1999). Posterior endoscopy is less aggressive and the risk of damage to the mucosa or bleeding is considerably lower (Willard and Radlinsky 1999). The major drawback of posterior rhinoscopy is the unaccessibility of choanae in dogs with a long nose and soft palate (Padrid and McKiernan 1999).

This paper summarises results of a project dealing with the use of endoscopic techniques in differential diagnostics and therapy of chronic diseases of the nasal cavity in dogs. Its objective was to compare the efficacy of examination of the nasal cavity by various endoscopic techniques and their combinations. 


\section{Materials and Methods}

Patients

The examinations were done at the Small Animal Clinic of the Faculty of Veterinary Medicine, University of Veterinary and Pharmaceutical Sciences, Brno. The set of patients included 56 dogs suffering from chronic nasal diseases. The patients were presented to the Clinic by agreement with collaborating practitioners. The introductory operations included the elaboration of anamnestic protocols and assessment of results of preceding clinical examinations (radiography) and laboratory findings (blood cell counts and biochemistry, culture of nasal swabs). Rhinoscopy was always preceded by detailed clinical examination of the patient, radiography of head and careful examination of dentition focused on lesions that may communicate with the nasal cavity. The patients were fasted for $12 \mathrm{~h}$ before the examination to prevent vomiting during general anaesthesia.

Anaesthesia

General condition of the patient and presumed duration of examination were considered in the choice of anaesthesia. The best results in premedication were obtained with diazepam (Seduxen inj., Gedeon Richter Ltd., 0.5 $-2 \mathrm{mg}$ per kg live weight i.v.), or medetomidin (Domitor inj. ad us. vet., Orion - Farmos, $0.01 \mathrm{mg}$ per kg live weight i.v.) combined with butorphanol (Beforal, Léčiva Inc., $0.2 \mathrm{mg}$ per kg live weight i.v.). Endotracheal tube was inserted before rhinoscopy to prevent inhalation of blood, secretions, vomits, or washing solutions. General anaesthetia was induced with ketamine (Narkamon inj., Léčiva Inc., 3 to $5 \mathrm{mg}$ per kg live weight i.v.). or propofol (Diprivan, Zeneca Ltd., 1 to $2 \mathrm{mg}$ per $\mathrm{kg}$ live weight i.v.). The combination medetomidin + butorphanol was used to prime patients for inhalation anaesthesia with halothane or isoflurane (Halothane liq., Léčiva Inc., Forane inh., Abbot Laboratories, Ltd.). The state of the patients during general anaesthesia was monitored with a pulsion oxymeter (SurgiVet V3301). The patients were examined in sternal recumbency with the chin stabilised in horizontal position with a support. Strong mouth gags were used to protect flexible endoscopes against damage by biting.

Anterior rhinoscopy

The rigid endoscope Hopkins (diameter $2.7 \mathrm{~mm}, 1.18 \mathrm{~cm}$, Karl Storz, Tuttlingen) was used. Its tip was introduced along the nasal septum, carefully leaned out and gently inserted. The nasal septum was reflected as a vertical area on the left or right side of the endoscope. In this way, all the three air passages were examined.

Posterior rhinoscopy

Posterior rhinoscopy was used to delineate the caudal margin of the lesion or to examine the nasopharynx. The flexible endoscope Olympus BT Type PR (Olympus Optical Comp., Hamburg) was inserted along the soft palate with the tip oriented rostrally. Turning the tip around the margin of the soft palate allowed the projection of nasopharynx and choanae. The image was reversed. Any manipulation in this region was strongly irritative. If biopsy was intended, the bioptic instrument was inserted through the flexible endoscope before bending it to avoid damage by pushing it through.

Biopsy

Tissue samples were collected from damaged mucosae or other structures of the nasal cavity with bioptic forceps (67167 Z, Karl Storz, Tuttlingen) under endoscopic control. More than one sample (mean 2 to 3 ) were collected upon each examination.

Prophylaxis of iatrogenic damage

After the sampling, the patients were treated with broad-spectrum antibiotics (amoxycillin, enrofloxacin, or cephalosporins as necessary considering the condition of the patient). Excessive bleeding was controlled by draining with physiological saline.

Histology

Bioptic samples for histological examination were fixed in $10 \%$ neutral formaldehyde for 12 to 24 hours and then processed by the conventional paraffin technique. Tissue sections ( 4 to $6 \mu$ ) were stained with haematoxylineosine. Differentiation of inflammatory and neoplastic lesions, determination of the individual inflammation types, classification of mesenchymal, epithelial, and round-cell tumours, and tentative identification of bacterial, parasitic, and fungal agents were carried out in the cytological laboratory of the Small Animal Clinic.

Definitive identification of infectious agents

Deep swabs were collected under rhinoscopic control from nasal lesions for definitive identification of pathogenic agents and antibiotic (antimycotic) resistance tests. The samples were transported to microbiological laboratories of the Faculty of Veterinary Medicine, Brno, or the State Veterinary Institute, Brno, in commercial transport media (Copan, Italy).

\section{Results}

The results are summarised in Tables 2 to 4 . Chronic diseases of the nasal cavity in the set of 52 dogs were diagnosed as bacterial rhinitis in $50 \%$, as mycotic rhinitis in $19.2 \%$, and as tumours in $23.1 \%$ of the patients. Foreign bodies were found in four $(7.7 \%)$ patients. 
Table 2

Applicability of rigid endoscopes to the diagnostics of diseases of the anterior and middle parts of the nasal cavity in dogs $(n=52)$

\begin{tabular}{|l|c|c|c|c|}
\hline Type of disease & \multicolumn{2}{|c|}{ Cases } & \multicolumn{2}{c|}{ Correct diagnosis } \\
\hline & Number & $\%$ & Number & 76.9 \\
\hline Bacterial rhinitis & $20 / 26$ & 76.9 & $4 / 26$ & 40.0 \\
\hline Mycotic rhinitis & $8 / 10$ & 80.0 & $2 / 12$ & 16.7 \\
\hline Tumour & $2 / 12$ & 16.7 & $3 / 4$ & 75.0 \\
\hline Foreign body & $2 / 4$ & 50.0 & & \\
\hline
\end{tabular}

Table 3

Applicability of flexible endoscopes to the diagnostics of diseases of the posterior part of the nasal cavity in dogs $(n=52)$

\begin{tabular}{|l|c|c|c|c|}
\hline Type of disease & \multicolumn{2}{|c|}{ Cases } & \multicolumn{2}{c|}{ Correct diagnosis } \\
\hline & Number & $\%$ & Number & 76.9 \\
\hline Bacterial rhinitis & $6 / 26$ & 23.1 & $3 / 26$ & 20.0 \\
\hline Mycotic rhinitis & $2 / 10$ & 20.0 & $8 / 10$ & 16.7 \\
\hline Tumour & $10 / 12$ & 83.3 & $1 / 4$ & 25.0 \\
\hline Foreign body & $2 / 4$ & 50.0 & & \\
\hline
\end{tabular}

Table 4

Comparison of reliability of histological examination of bioptic samples and swab culture $(n=36)$

\begin{tabular}{|c|c|c|}
\hline Type of disease & Bioptic samples & Swabs \\
\hline Bacterial rhinitis & $26 / 26(100.0 \%)$ & $10 / 26(38.5 \%)$ \\
\hline Mycotic rhinitis & $8 / 10(80.0 \%)$ & $5 / 10(50.0 \%)$ \\
\hline
\end{tabular}

Anterior rhinoscopy

The most conspicuous lesions found in the patients suffering from chronic rhinitis included severe hyperaemia and erosions and ulceration affecting the continuity of the nasal mucosa. Typical fungal plaques on the nasal mucosa were found in three patients suffering from mycotic rhinitis (aspergillosis). Neoplasms in the nasal cavity were associated with the limitation of air passage, hyperaemia of the nasal mucosa and proneness to severe bleeding. Complete block of passage of the endoscope through the middle air passage was found in two patients. Destructive rhinitis was observed above all in patients suffering from chronic conditions (aspergillosis, foreign body, chronic bacterial rhinitis). Marked spatial limitation of airways in such patients was due to swelling of the nasal mucosa and accumulation of mucus which also concealed lesions that would be detected by rhinoscopy otherwise. Thus, we failed to recognise by rhinoscopy the presence of fibrosarcomas or mycotic granulomas (aspergillosis) in five patients.

Posterior rhinoscopy

The introduction of endoscope along the long soft palate was rather complicated in five dogs with relatively long nasal cavities (Collie, Retriever, Doberman, German Shepherd Dog, Rhodesian Ridgeback). The nasopharyngeal mucosa, which is smooth and pink in normal dogs, became strongly hyperaemic and very prone to bleeding after even a slight irritation in dogs affected by tumours. Increased amount of mucus and lymphoid follicular hyperplasia were also observed.

A comparison of clinical findings in the set of dogs under study indicates that anterior rhinoscopy with a rigid endoscope alone yielded correct diagnosis in $55.8 \%$ of the patients. 
Posterior rhinoscopy with a flexible endoscope proved to be purposeful in $26.9 \%$ of the patients. The most reliable was the examination by both the techniques which yielded correct diagnoses in $82.7 \%$ of the patients.

In most patients, biopsies were followed by moderate bleeding which ceased within a few minutes. Severe bleeding was observed in 8 patients only. Endoscopic control facilitated the selection of a suitable sampling site and reduced the danger of injury to the mucosa. The risk of blood aspiration was eliminated by endotracheal intubation. All rhinoscopies were carried out in deep general anaesthesia. As soon as some reaction of the patient was observed, the anaesthesia was deepened by intravenous administration of propofol and the examination was interrupted for the necessary time. No reactions were observed in patients in inhalation anaesthesia.

Histological examination of samples collected by endoscope-assisted biopsy yielded correct diagnosis in 34 of the 36 patients $(94.4 \%)$, while bacteriological and mycological examination of swabs in only 15 of the 36 patients (41.7\%).

\section{Discussion}

Most of the clinical manifestations seen in patients affected by diseases of the nasal cavity were nonspecific and, therefore, their differential diagnostic value was limited. Clinical examination includes the assessment of the amount and appearance of nasal discharge, deformation of nostrils and the facial area, head posture, ocular discharge, the state of periodontium and teeth of the upper jaw, and clefts and fistules of the hard and soft palates, if present. Exact diagnostics of nasal diseases must include also radiographic and endoscopic examinations (Padrid and McKiernan 1999; Willard and Radlinsky 1999).

Examination of a set of radiographs allows the surgeon to estimate the extent, character, and severity of lesions and to determine the most suitable site for biopsy when appropriate. Most of the neoplastic processes have their origin in the area of lamina cribrosa of the ethmoid bone. Destructive and hyperplastic rhinitis affect the central and rostral parts of the nasal cavity. Unilateral and bilateral obstructions result mostly from neoplasia and chronic inflammatory processes, respectively. External findings are inconclusive in most cases and the examination must be completed by rhinoscopy.

Dogs are very sensitive to any interventions in the nasal cavity and, therefore, rhinoscopy must be carried out in deep general anaesthesia (Padrid and McKiernan 1999; Robertson 1999). Any contact with a damaged mucosa is very painful in patients affected by chronic rhinitis. Therefore, some authors recommend potentiation of analgesia with phentanyl (Robertson 1999). Butorphanol, used in our patients, proved to be effective enough, too. Local anaesthesia is insufficient and impractical because of a rapid drainage of the drug with discharge and blood, and limitation of air passage. Therefore, local anaesthesia was avoided in our examinations. General anaesthesia can be induced by intravenous administration of anaesthetics, such as thiopental, propophol, or ketamine (Roberts on 1999). Our examinations demonstrated a very good efficacy of propophol. Inhalation anaesthesia with halothane or isoflurane provides a high safety to the patient and undisturbed conditions for the surgeon. Our experience has confirmed the information published by (Padrid and McKiernan 1999) recently.

In spite of all its merits, rhinoscopy without histological examination of tissue samples can provide conclusive diagnosis in only a limited number of cases. Sampling for histological examination is a part of endoscopic examination which localises the lesion and delimits its extent. Generally, histological examination of bioptic samples should be preferred to cytological examination of swabs which, in most cases, only demonstrates secondary inflammatory responses developing also in patients affected by nasal tumours. The samples are collected with bioptic forceps or a catheter adapted for this purpose (Padrid 
and McKiernan 1999). The sample should be as thick as possible to get also a part of the submucosal layers. To increase the reliability of diagnosis, it is recommended to collect and examine at least three samples. The principal safety rule is that bioptic forceps must not penetrate into the nasal cavity deeper than to the medial eye angle. Otherwise, the instrument could penetrate through the medial wall of the orbit, or through the frontal sinus, and damage the eye ball, or the brain, respectively. Therefore, we measured the distance between nostrils and the medial eye angle in all the patients before inserting the endoscope. The maximum safe depth of insertion can be marked on the endoscope.

Within our studies, anterior rhinoscopy with a rigid endoscope yielded correct diagnosis in $55.8 \%$ of the cases. The use of a flexible bronchoscope was indicated particularly in cases where the process was localised in the posterior part of the nasal cavity. Examination by the two techniques yielded reliable diagnosis in $82.7 \%$ of our patients. This combination has been recommended for the examination of the nasal cavity of small animals also by other authors (Padrid and McKiernan 1999; Willard and Radlinsky 1999).

Bacteria of the genera Pseudomonas, Pasteurella, and Staphylococcus are known to be the major causative agents identified in cases of bacterial rhinitis. In our investigations, bacteria of the genera Staphylococcus and Pseudomonas were isolated from the anterior part of the nasal cavity most frequently. Similar results were obtained also in other studies (Caniatti et al. 1998a; Forbes Lent and Hawkins 1992; Knotek et al. in press). The most reliable method for the diagnosis of bacterial rhinitis was histological examination of bioptic samples; culture of deep swabs from the nasal cavity often yielded false negative results.

In addition to erosions, mycotic plaques were demonstrated by anterior rhinoscopy in three dogs affected by aspergillosis. However, absence of plaques does not preclude the diagnosis of aspergillosis. The interpretation of radiograms in patients suspected of aspergillosis shall focus on the assessment of symmetry. Increased radiolucence and radiodensity are indicative of osteolytic processes and cumulation of exudate, respectively. If present, exudate cumulates above all in frontal sinuses. The most reliable diagnostic method is microscopic demonstration of the causative agent in bioptic samples. Since the infection is multifocal in most cases, it is recommendable to collect more than one bioptic sample. Causative agents of mycotic rhinitis in dogs include Aspergillus spp. (A. fumigatus, less frequently A. niger, A. nidulans, and A. flavus) and Penicillium spp. (Caniatti et al. 1998a; Forbes Lent and Hawkins 1992). In our earlier investigations, mycotic rhinitis was often associated with a foreign body in the nasal cavity (Kn otek et al. in press). Results of neither radiographic examination, nor rhinoscopy were conclusive for the diagnosis of aspergillosis unless they are completed by microscopic examination of bioptic samples. Absence of mycotic plaques makes the differentiation of bacterial, mycotic and mixed rhinitis difficult.

Injury to the nasal mucosa can be followed by secondary bacterial or mycotic rhinitis. Radiographic examination can demonstrate only radiodense foreign bodies, such as tooth, bone, or wire. In such cases, radiography is irreplaceable, because it can reveal the primary cause of chronic rhinitis. Foreign body can be removed under endoscopic control. The choice of the endoscope type (rigid or flexible) depends on the size and position of the foreign body (Tyler 1997; Willard and Radlinski 1999). Small bodies in the rostral od middle part of the nasal cavity can be removed with endoscopic forceps or forceps, while foreign bodies in the area of choanae are better removed under the control of a flexible endoscope introduced along the soft palate. Larger foreign bodies are difficult to remove through the endoscopic tube (Willard and Radlinski 1999).

Chronic discharge from nostrils can be caused also by nasal tumours that account for 0.2 to $2.4 \%$ of all canine tumours (Ogilvie and LaRue 1992). Their occurrence is higher in 
older patients. Willard and Radlinski (1999) diagnosed by endoscopy tumours in 33\% of patients with nasal problems. Most of them were malignant. Adenocarcinomas, squamous carcinomas, and undifferentiated carcinomas accounted for $60 \%$ of oncological findings. Fibrosarcomas, chondrosarcomas and osteosarcomas were diagnosed less frequently and the rest came to other tumour types, such as neuroblastomas, neuroendocrine tumours, melanomas, fibromas, and chondromas. In our earlier study, malignant tumours were diagnosed in 12 of the 43 dogs (27\%) examined by nasal endoscopy (K notek et al. in press). Most tumours (often very large) were found in the posterior part of the nasal cavity. Therefore, posterior rhinoscopy and its combination with anterior rhinoscopy were more effective in the detection of nasal tumours. Similarly, Willard and Radlinski (1999) estimated the reliability of posterior rhinoscopy with a flexible endoscope in the diagnostics of tumours located in the area of choanae to $73.7 \%$. The applicability of this technique is limited in dogs with longer noses. In our examinations, we experienced this problem in five dogs (Collie, Retriever, Doberman, German Shepherd Dog, and Rhodesian Ridgeback).

Rhinoscopy, in particular anterior rhinoscopy with a rigid endoscope combined with posterior rhinoscopy with a flexible endoscope, have allowed a significant advance in coping with the problem of chronic nasal diseases in dogs. In addition to the visual finding, these techniques allow accurate and safe collection of bioptic samples for histological examination.

\section{Diagnostika chronických onemocnění dutiny nosní u psů s využitím endoskopické techniky}

Předkládaná práce shrnuje výsledky projektu uskutečněného v letech 1999 - 2000 u 52 psů trpících chronickým onemocněním dutiny nosní. Cílem bylo porovnat efektivnost vyšetření dutiny nosní jednotlivými endoskopickými přístupy a jejich společnou kombinací. K vyšetř̌ení byl použit rigidní endoskop Hopkins $(\varnothing 2,7 \mathrm{~mm}, 18 \mathrm{~cm}$, Karl Storz, Tuttlingen) a flexibilní endoskop (Olympus BF typ PE, Olympus Optical Co., Hamburg). Vzorky tkání z míst poškození sliznice a narušené vnitřní architektury nosní dutiny byly pod kontrolou endoskopu odebrány bioptickými nůžkami, fixovány v $10 \%$ neutrálním pufrovaném formalínu (doba fixace 12-24 hodin) a zpracovány běžnou parafinovou technikou. Pod kontrolou rinoskopu byly provedeny i hluboké výtěry $\mathrm{z}$ poškozených míst pro bakteriologickou a mykologickou diagnostiku. Chronické onemocnění souviselo $\mathrm{s}$ bakteriální rinitidou $(50,0 \%$ př́padů), mykotickou rinitidou ( $19,2 \%$ př́padů) a neoplaziemi ( $23,1 \%$ případů). Ve 4 př́ípadech byla potvrzena prítomnost cizího tělesa. $U 3$ př́padů mykotické rinitidy byly na sliznici pozorovány fungální plaky. U 2 prípadů neoplazie byla pozorována kompletní blokáda průchodu endoskopu do střední části dutiny nosní. Destruktivní rinitida se vyskytovala především u pacientů s chronickými potižemi (aspergilóza, přítomnost cizího tělesa, chronická bakteriální infekce). 55,8 \% správně určených nálezů bylo diagnostikováno s pomocí rinoskopie přední části dutiny nosní pomocí rigidního endoskopu. Technika rinoskopie zadní části dutiny nosní využívající flexibilní bronchoskop byla přínosem především v $26,9 \%$ př́padů. Kombinací obou technik bylo přesně diagnostikováno $82,7 \%$ vyšetřovaných případủ. Z porovnání $94,4 \%$ spolehlivosti výsledků histologického vyšetření bioptátů dutiny nosní pořízených pomocí rinoskopie s 41,7\% výsledky jiných laboratorních vyšetření je patrné, že rinoskopie představuje výrazný pokrok v řešení problematiky chronických onemocnění dutiny nosní u psů.

\section{Acknowledgements}

This work is a part of project supported by the Ministry of Education CR (grant No. 161700002). The authors are grateful to Dr. P. Raušer for his technical assistance in anaesthesia of the animals. The authors wish to thank Ms V. Vyhlídalová for competent technical assistance throughout the preparation of samples for histological examination. 


\section{References}

CANIATTI, M., ROCCABIANCA, P., GHISLENI, G., MORTELLARO, C.M., ROMUSSI, S., MANDELLI, G. 1998a: Evaluation of brush cytology in the diagnosis of chronic intranasal disease in cats. J. Small Anim. Pract. 39: $73-77$

CANIATTI, M., ROCCABIANCA, P., SCANZIANI, E., FINAZZI, M., MORTELLARO, C. M., ROMUSSI, S., MANDELLI, G. 1998b: Nasal rhinosporidiosis in dogs: four cases from Europe and a review of the literature. Veterinary Record 142: $334-338$

COWELL, R. L., TYLER, R. D., MEINKOTH, J. H. 1999: Diagnostic Cytology and Hematology of the Dog and Cat, Mosby, St. Luis, $52-58$

FORBES LENT, S. E., HAWKINS, E. C. 1992: Evaluation of rhinoscopy and rhinoscopy-assisted mucosal biopsy in diagnosis of nasal disease in dogs: 119 cases (1985 - 1989). J. Amer. Vet. Med. Assoc. 201: 1425 - 1429

KNOTEK, Z., FICHTEL, T., KOHOUT, P., BENÁK, J.: Nemoci dutiny nosní psa a kočky. Etiologie, symptomatologie, diagnostika. Acta Vet. Brno - in press

McCULLOUGH, S. M., KIERNAN, B. C., GRODSKY, B. S. 1998: Endoscopically placed tubes for administration of enilconazole for treatment of nasal aspergillosis in dogs. J. Amer. Vet. Med. Assoc. 212: 67 - 69

MEYER, J. B. 1987: The management of cytology specimens. Comp. Cont Educ. Pract. Vet. 9:10-16

NIELSEN, S. W., KENNEDY, P. C. 1990: in: Moulton, J. E. Tumors in Domestic Animals. 3.ed, Univ California Press, Berkeley, 498 - 502

OGILVIE, G. K., LaRUE, S. 1992: Canine and feline nasal and paranasal sinus tumors. Vet. Clin. North Amer. 22: $1133-1144$

PADRID, P. A., McKIERNAN, B. C. 1999: Endoscopy of the upper respiratory tract of the dog and cat. in: Tams. T.R. Small animal endoscopy. 2. ed. Mosby, St. Louis, $357-376$

REBAR, A. H., HAWKINS, E. C., DeNICOLA, D. B. 1992: Cytologic evaluation of the respiratory tract. Vet. Clin. North Amer. 22: 1065 - 1085

ROBERTSON, S. A. 1999: Newer diagnostic and surgical techniques and their impact on anesthesia. Vet. Clin. North. Amer. 29: 665 - 682

ROBINSON, N.E. 1992: Airway physiology. Vet. Clin. North. Amer. 22: 1043 - 1064

SULLIVAN, M. 1987: Rhinoscopy: a diagnostic aid? J. Small. Anim. Pract. 28: 839 - 844

THÉON, A. P., MADEWELL, B. R., SHEARN, V. I., MOULTON, J. E. 1995: Prognostic factors associated with radiotherapy of squamous cell carcinoma of the nasal plane in cats. J. Amer. Vet. Med. Assoc. 206: 991 - 997

TYLER, J. V. 1997: Endoscopic retrieval of a large nasopharyngeal foreign body. J. Amer. Anim. Hosp. Assoc. 33: $513-516$

Van PELT, D.R., McKIERNAN, B. C. 1994: Pathogenesis and treatment of canine rhinitis. Vet. Clin. North. Amer. 24: $789-806$

VOKURKA, J., ŠLAPÁK, I., HYBÁŠEK, I. 1998: Endoskopické endonazální operace. Acta Fac. Med. Univ Brunensis Masarykianae, Brno, $116 \mathrm{p}$.

WILLARD, M. D., RADLINSKY M. A. 1999: Endoscopic examination of the choanae in dogs and cats: 118 cases (1988 - 1998). J. Amer. Vet. Med. Assoc. 215: 1301 - 1305

WOLF, A. M. 1992: Fungal diseases of the nasal cavity of the dog and cat. Vet. Clin. North. Amer. 22: 1119 - 1131 